\title{
МЕТОДИЧНЕ ЗАБЕЗПЕЧЕННЯ ВНУТРІШНЬОГО КОНТРОЛЮ ЗОВНІШНЬОЕКОНОМІЧНОї ДІЯЛЬНОСТІ ПІДПРИЕМСТВ ТОРГІВЛІ
}

\section{METHODOLOGICAL SUPPORT OF INTERNAL CONTROL OF FOREIGN ECONOMIC ACTIVITY OF TRADE ENTERPRISES}

\author{
Кінзерська Наталія Вікторівна \\ аспірант, \\ Національна академія статистики, обліку та аудиту \\ ORCID: https://orcid.org/0000-0002-7306-9645 \\ Kinzerska Natalia \\ National Academy of Statistics, Accounting and Audit
}

\begin{abstract}
У статті висвітлено проблемні питання формування методичного забезпечення внутрішнього контролю зовнішньоекономічної діяльності підприємств торгівлі. Виокремлені основні вимоги, яким повинна відповідати система внутрішнього контролю зовнішньоекономічної діяльності в умовах ризику. Уточнено перелік об'єктів внутрішнього контролю зовнішньоекономічної діяльності в умовах ризику. Розроблено методичне забезпечення та виокремлено основні етапи здійснення внутрішнього контролю зовнішньоекономічної діяльності. 3 метою належного документального офрормлення процедур внутрішнього контролю зовнішньоекономічної діяльності та їх результатів запропоновані форми робочих документів суб'єктів внутрішнього контролю. Для узагальнення результатів внутрішнього контролю зовнішньоекономічної діяльності запропоновано складати Звіт про результати внутрішнього контролю здійснення зовнішньоекономічних операцій та Звіт про результати внутрішнього контролю ризиків ЗЕД, використання яких дозволить на належному рівні систематизувати причини виникнення недоліків та відхилень, а також шляхи їх усунення та запобігання виникнення в майбутньому.

Ключові слова: внутрішній контроль, методичне забезпечення, зовнішньоекономічна діяльність, ризик, робочі документи суб'єкта внутрішнього контролю.
\end{abstract}

В статье освещены проблемные вопросы формирования методического обеспечения внутреннего контроля внешнеэкономической деятельности предприятий торговли. Выделены основные требования, которым должна соответствовать система внутреннего контроля внешнеэкономической деятельности в условиях риска. Уточнен перечень объектов внутреннего контроля внешнеэкономической деятельности в условиях риска. Разработано методическое обеспечение и выделены основные этапы осуществления внутреннего контроля внешнеэкономической деятельности. С целью надлежащего документального оформления процедур внутреннего контроля внешнеэкономической деятельности и их результатов, предложенные формы рабочих документов субъектов внутреннего контроля. Для обобщения результатов внутреннего контроля внешнеэкономической деятельности предложено составлять Отчет о результатах внутреннего контроля осуществления внешнеэкономических операций и Отчет о результатах внутреннего контроля рисков ВЭД, использование которых позволит на должном уровне систематизировать причины возникновения недостатков и отклонений, а также пути их устранения и предотвращения возникновения в будущем.

Ключевые слова: внутренний контроль, методическое обеспечение, внешнеэкономическая деятельность, риск, рабочие документы субъекта внутреннего контроля.

The functioning of trade enterprises in conditions of uncertainty and the negative impact of inflation and restrictive processes leads to an increase in the negative impact of foreign economic activity risks on financial results. The expansion of the objects of internal control, the complication of the effective implementation of control procedures, the need to expand the methods of internal control necessitate the development and improvement of methodological support for internal control of foreign economic activity. The purpose of writing the article is to develop and improve the methodological support of internal control of foreign economic activity of trade enterprises in conditions of risk. Construction of methodological support for internal control of foreign economic activity involves 
the identification of stages and procedures of internal control of foreign economic transactions at different stages of their implementation. According to the results of the study, the list of objects of internal control of foreign economic activity in conditions of risk has been clarified. Methodological support has been developed and the main stages of internal control of foreign economic activity have been singled out. In order to properly document the procedures of internal control of foreign economic activity and their results, the forms of working documents of the subjects of internal control are proposed. To summarize the results of internal control of foreign economic activity, it is proposed to compile a Report on the results of internal control of foreign economic transactions and a Report on the results of internal control of foreign trade risks, the use of which will properly systematize the causes of shortcomings and deviations. The practical significance of the study is the proper streamlining and effective implementation of internal control of foreign economic activity, which will promote compliance with management policies in terms of preserving the property of the enterprise and ensure proper documentation and accounting of foreign economic transactions taking into account the impact of risks.

Keywords: internal control, methodological support, foreign economic activity, risk, working documents of the subject of internal control.

Функціонування підприємств торгівлі в умовах невизначеності, негативного впливу інфляяційних та обмежувальних процесів, призводить до підвищення негативного впливу ризиків зовнішньоекономічної діяльності на фрінансові результати. Розширення об'єктів внутрішнього контролю, ускладнення ефективного виконання контрольних процедур, необхідність розширення методів внутрішнього контролю зумовлюють потребу розвитку та удосконалення методичного забезпечення внутрішнього контролю зовнішньоекономічної діяльності. Метою написання статті $€$ розвиток та удосконалення методичного забезпечення внутрішнього контролю зовнішньоекономічної діяльності підприємств торгівлі в умовах ризику. Побудова методичного забезпечення внутрішнього контролю зовнішньоекономічної діяльності передбачає ідентисрікацію етапів, стадій та процедур внутрішнього контролю здійснення зовнішньоекономічних операцій на різних етапах їх виконання. За результатами дослідження уточнено перелік об'єктів внутрішнього контролю зовнішньоекономічної діяльності в умовах ризику. Розроблено методичне забезпечення та виокремлено основні етапи здійснення внутрішнього контролю зовнішньоекономічної діяльності. 3 метою належного документального офрормлення процедур внутрішнього контролю зовнішньоекономічної діяльності та їх результатів запропоновані форми робочих документів суб'єктів внутрішнього контролю. Для узагальнення результатів внутрішнього контролю зовнішньоекономічної діяльності запропоновано складати Звіт про результати внутрішнього контролю здійснення зовнішньоекономічних операцій та Звіт про результати внутрішнього контролю ризиків ЗЕД, використання яких дозволить на належному рівні систематизувати причини виникнення недоліків та відхилень, а також шляхи їх усунення та запобі- гання виникнення в майбутньому. Практичне значення проведено дослідження полягає у належному упорядкуванні і ефрективному здійсненні внутрішнього контролю зовнішньоекономічної діяльності, сприятиме дотриманню політики управлінського персоналу в частині збереження майна підприємства та забезпечить правильне документування та облікове відображення зовнішньоекономічних операцій з урахуванням впливу ризиків.

Постановка проблеми. Створення належних передумов для збереження майна підприємства, підвищення показників прибутковості його діяльності, передбачає формування відповідного механізму внутрішнього контролю. Методичне забезпечення внутрішнього контролю зовнішньоекономічної діяльності підприємств торгівлі (далі - ЗЕД) втілюється в розробці теоретичних та прикладних положень щодо його здійснення. Формування алгоритмів здійснення внутрішнього контролю ЗЕД в умовах впливу факторів невизначеності та дії ризиків, актуалізує розробку та оновлення існуючих методичних підходів до здійснення внутрішнього контролю зовнішньоекономічних операцій. Побудова методичного забезпечення внутрішнього контролю ЗЕД в умовах розширення ссрер та об'єктів внутрішнього контролю передбачає ідентифрікацію етапів, стадій та процедур внутрішнього контролю здійснення зовнішньоекономічних операцій на різних етапах їх виконання.

«Зовнішньоекономічна діяльність $€$ достатньо складним і ризикованим процесом. Суб'єкти господарювання припускаються помилок під час проведення операцій у ссрері ЗЕД, несуть значні фрінансові втрати. Щоб уникнути таких втрат, управлінський персонал підприємств має бути обізнаним щодо організації, обліку, звітування, оподаткування зовнішньоекономічних операцій» [6, с. 45]. Наявність зазначених проблемних питань, 
підвищує актуальність розробки методичного забезпечення внутрішнього контролю здійснення зовнішньоекономічних операцій суб'єктами господарювання в умовах нестабільного економічного середовища.

Аналіз останніх досліджень і публікацій. Вагомий внесок у дослідження питання розробки методичних засад здійснення внутрішнього контролю, аудиту ЗЕД зробили як вітчизняні так і зарубіжні науковці. Зокрема, практичні аспекти здійснення перевірок в сорері здійснення ЗЕД були досліджені такими авторами, як: Бабій Л.І., Бєляков О.О., Букреєва Н.П., Венцель В.Т., Книшек О.О., Коблянська Г.Ю., Кожухова Т.В., Мельничук І.В., Лубенченко О.Е., Федькевич Н.В. та інші.

Виділення невирішених раніше частин загальної проблеми. На сьогодні питання розвитку методичного забезпечення внутрішнього контролю ЗЕД потребує додаткових досліджень та наукового обґрунтування, зважаючи на значний вплив ризиків ЗЕД на фрінансові результати діяльності підприємств торгівлі.

Формулювання цілей статті (постановка завдання). Метою даної статті $€$ розвиток та удосконалення методичного забезпечення внутрішнього контролю зовнішньоекономічної діяльності підприємств торгівлі в умовах ризику.

Виклад основного матеріалу дослідження. Розвиток та удосконалення методичного забезпечення внутрішнього контролю ЗЕД в умовах ризику слід здійснювати із застосуванням системного підходу, що в подальшому сприятиме належній результативності та раціональності виконання функцій суб'єктами контролю. Основними завданнями внутрішнього контролю зовнішньоекономічної діяльності підприємства є такі:

- формування впевненості в управлінського персоналу в частині досягнення запланованих результатів здійснення зовнішньоекономічної діяльності та основної мети діяльності підприємства;

- забезпечення раціонального використання ресурсів підприємства та підвищення ефрективності виконання умов ЗЕД контрактів;

- своєчасна ідентифрікація, оцінка та мінімізація наслідків впливу ризиків здійснення зовнішньоекономічних операцій;

- оперативне реагування та гнучкість пристосування підприємства до змін внутрішнього та зовнішнього середовища в ссрері здійснення зовнішньоекономічної діяльності;

- забезпечення дотримання вимог законодавства в сорері ЗЕД, повноти і достовірності орінансової звітності підприємства;
- дотримання вимог внутрішніх розпорядчих та регламентаційних документів в частині виконання бізнес-процесів в сорері виконання умов договорів ЗЕД тощо.

Реалізація завдань системи внутрішнього контролю ЗЕД в умовах ризику забезпечується шляхом фрормування належного методичного забезпечення та механізмів контролю, які забезпечать ефрективне здійснення бізнес-процесів в сорері ЗЕД. Основними вимогами, яким повинна відповідати система внутрішнього контролю в даному випадку повинні бути такі:

- система внутрішнього контролю ЗЕД повинна бути невід'ємною частиною системи управління суб'єкта господарювання;

- необхідно використовувати ризик-орієнтований підхід при фрормуванні та визначенні переліку об'єктів внутрішнього контролю ЗЕД;

- своєчасно виявляти нові ризики ЗЕД, оцінювати їх вплив та фрормувати інструментарій для мінімізації наслідків їх виникнення;

- підлягати постійному моніторингу та удосконаленню для забезпечення результативності та ефрективності здійснення контрольних процедур;

- формувати належні комунікаційні зв'язки між різними структурними підрозділами підприємства в частині обміну інфрормацією про недоліки здійснення зовнішньоекономічних операцій;

- містити процедури оперативного повідомлення інформації про відхилення та помилки при здійсненні та обліковому відображенні зовнішньоекономічних операцій.

Одним із основних моментів, від якого залежить побудова методичного забезпечення внутрішнього контролю ЗЕД $є$ формування переліку об'єктів внутрішнього контролю. Дослідження наукових публікацій та джерел дозволило встановити, що серед авторів щодо даного питання відсутня одностайність думок, зокрема:

1. Венцель В.Т. [2, с. 13] запропонував «об'єкти внутрішнього контролю, пов'язані 3 експортно-імпортними операціями, розподілити за трьома групами: майно (активи), капітал та зобов'язання; господарські процеси та їх результати; діяльність структурних підрозділів, посадових осіб, що дозволило визначити напрями організації контролю та його методичне забезпечення».

2. Глущенко Я.І. [3, с. 64] розширює перелік об'єктів контролю ЗЕД, виокремлюючи «зовнішньоекономічний договір, як окремий об'єкт внутрішнього контролю, акцентуючи 
увагу на визначенні мети, суб'єктів, джерел інфрормації, методичних способах і прийомах контролю».

3. Бовтун О.Л. [1, с. 13] до об'єктів аудиту зовнішньоекономічних операцій відносить: «а) об'єкти, що забезпечують зовнішньоекономічну діяльність (матеріальні та нематеріальні активи, одержані в результаті імпортних операцій; іноземна валюта в касі та на рахунках у банку; заборгованість іноземних покупців та інших контрагентів; заборгованість перед іноземними постачальниками та іншими контрагентами; заборгованість по авансах, виданих або одержаних в іноземній валюті; доходи та втрати від операційних та неопераційних курсових різниць; дебіторська та кредиторська заборгованість підзвітних осіб по закордонних відрядженнях; розрахунки з іноземними засновниками по внесках до статутного капіталу; кредити банку, одержані в іноземній валюті; інші статті, виражені в іноземній валюті; б) об'єкти, що створюють зовнішньоекономічну діяльність (імпортні операції та їх результат; експортні операції та їх результат); в) об'єкти, що характеризують організацію зовнішньоекономічної діяльності: наявність або відсутність спеціальних відділів, що регулюють ЗЕД (планових, облікових, контролюючих тощо)»;

4. Добровольська В.В. зазначає, що «об'єктами контролю у сорері ЗЕД $є$ відносини й діяльність суб'єктів господарювання (резидентів і нерезидентів) з приводу їх здійснення, яка, як правило, опосередковується укладанням і виконанням зовнішньоекономічного контракту [4].

Враховуючи наявність диференційованих підходів до визначення переліку об'єктів контролю ЗЕД, вважаємо, що їх складу мають належати: безпосередньо господарські операції та процеси, а також їх результати, активи, капітал та зобов'язання, які виникають в ході здійснення таких господарських операцій в сорері ЗЕД. Забезпечення безперервності процесу внутрішнього контролю ЗЕД базується на розробці та використанні процедур попереднього, поточного та наступного контролю (рис. 1).

Попередній контроль здійснюється на етапі здійснення договірної роботи, фрормування положень ЗЕД контрактів, попередньої оцінки ризиків, які можуть виникати з умов договору. Зокрема, Глущенко Я.І. [3, с. 66] в ході здійснення внутрішнього контролю зовнішньоекономічного договору (контракту) виокремлює наступні його об'єкти:
1. Доцільність укладання договору (контракту) з обраним контрагентом (репутація контрагента; надійність фрінансового стану контрагента);

2. Відповідність умов договору (контракту) діючим нормативно-правовим актам;

3. Виконання умов договору (контракту) (своєчасність і повнота поставки товару (надання послуг, виконання робіт), дотримання базисних умов поставки; правильність визначення купівельної ціни, митної вартості, податків, пов'язаних з виконанням зовнішньоекономічного договору; своєчасність та повнота оплати за зовнішньоекономічним договором).

Аналогічного підходу дотримуються В.В. Євдокимов та В.Т. Венцель, зазначаючи, що «початком контролю експортно-імпортних операцій можна вважати контроль контрактної діяльності підприємства» [5, с. 80].

Поточний контроль повинен здійснюватися безпосередньо в момент здійснення господарської операції або процесу в сорері ЗЕД. Основним завданням поточного контролю ЗЕД в умовах ризику є своєчасне виявлення відхилень та недоліків в частині здійснення різного типу зовнішньоекономічних операцій, а також усунення або мінімізація негативного впливу ризиків на задані параметри здійснення ЗЕД.

На етапі поточного контролю залежно від обраного об'єкту контролю та напряму здійснення внутрішнього контролю, суб'єкти внутрішнього контролю повинні перевірити:

- правомірність та умови здійснення ЗЕД суб'єктом господарювання (наявність дозволів, ліцензій, квот);

- повноту та якість документального оформлення в частині підтвердження здійснення зовнішньоекономічних операцій, правильність їх складання;

- дотримання вимог бухгалтерського законодавства в частині бухгалтерського обліку зовнішньоекономічних операцій;

- правильність застосування курсів валют та розрахунку курсових різниць, їх відображення у складі доходів та витрат підприємства;

- випадки порушення договірних умов та причин їх виникнення;

- своєчасність здійснення розрахунків за договорами ЗЕД та кредитно-валютних операцій, встановлення помилок у бухгалтерському та податковому обліку операцій з купівлі-продажу валюти та порядку її використання;

- правильність складання договорів ЗЕД, спрямування їх умов на мінімізацію виникнення ризиків, відповідність вимогам національного та міжнародного права; 


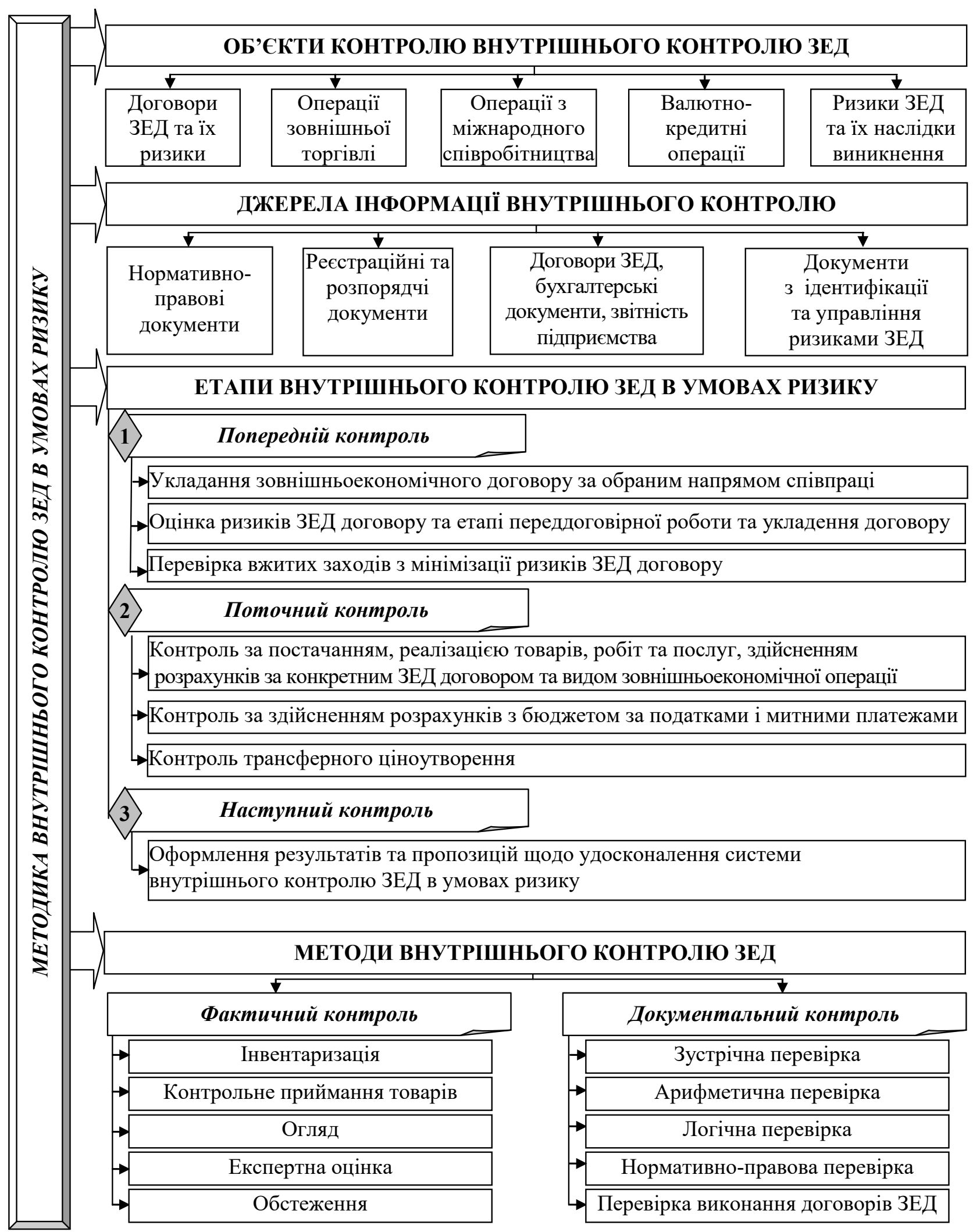

Рис. 1. Методика внутрішнього контролю ЗЕД в умовах ризику

- митне оформлення товарів, нарахування та сплати податків та зборів при здійсненні зовнішньоекономічних операцій;

- правильність визнання та повноту відображення на рахунках бухгалтерського обліку доходів і витрат від здійснення зовнішньоекономічної діяльності;

- своєчасність формування документів 3 ідентисрікації та оцінки ризиків ЗЕД, визначення наслідків їх впливу на фрінан- 
сові результати суб'єкта господарювання тощо.

На етапі поточного контролю особливу увагу слід приділити здійсненню контролю за здійсненням розрахунків з бюджетом за податками і митними платежами. Зокрема, суб'єктами внутрішнього контролю повинна здійснюватися перевірка наступних господарських операцій:
- визначення та перевірка обґрунтованості бази оподаткування за результатами здійснених зовнішньоекономічних операцій;

- перевірка відображення на рахунках бухгалтерського обліку ПДВ, митних платежів та їх відповідність підтверджуючим документам (вантажна митна декларація, довідка про сплату мита, акцизного податку тощо);

Запропоновані форми робочих документів суб'єктів внутрішнього контролю

Таблиця 1 в сорері перевірки зовнішньоекономічних операцій

\begin{tabular}{|c|c|c|c|}
\hline $\begin{array}{l}\text { Назва робочого } \\
\text { документу }\end{array}$ & $\begin{array}{c}\text { Призначення } \\
\text { робочого документу }\end{array}$ & $\begin{array}{c}\text { Основні показники, } \\
\text { що містяться В } \\
\text { робочому документі }\end{array}$ & \begin{tabular}{|c|} 
Періодичність, \\
особа відповідальна \\
за складання \\
документу \\
\end{tabular} \\
\hline \begin{tabular}{|l|} 
Протокол перевірки \\
зовнішньоекономічних \\
договорів та оцінка \\
ризиків їх виконання
\end{tabular} & \begin{tabular}{|l|} 
Сорормувати \\
інорормаційний \\
базис та здійснити \\
оцінку правильності \\
фрормування умов \\
договорів ЗЕД, \\
спрямування їх змісту \\
на мінімізацію ризиків \\
ЗЕД
\end{tabular} & \begin{tabular}{|l|} 
Результати перевірки \\
істотних умов \\
договору та їх \\
відповідність вимогам \\
законодавства; \\
оцінка достатності \\
заходів спрямованих \\
на удосконалення \\
змісту ЗЕД договорів \\
в напрямку мінімізації \\
ризиків ЗЕД \\
\end{tabular} & $\begin{array}{l}\text { щоквартально, } \\
\text { керівник } \\
\text { юридичного відділу, } \\
\text { керівник відділу } \\
\text { зовнішньоекономічної } \\
\text { діяльності, керівник } \\
\text { служби внутрішнього } \\
\text { контролю }\end{array}$ \\
\hline $\begin{array}{l}\text { Акт перевірки } \\
\text { облікового } \\
\text { відображення } \\
\text { експортно-імпортних } \\
\text { операцій та ризиків їх } \\
\text { здійснення }\end{array}$ & \begin{tabular}{|l|} 
Надати інсрормацію \\
щодо відхилень \\
та помилок у \\
бухгалтерському \\
обліку експортно- \\
імпортних операцій та \\
ризиків їх здійснення
\end{tabular} & \begin{tabular}{|l|} 
Вид \\
зовнішньоекономічної \\
операції та її обсяг, \\
підтверджуючі \\
документи, оцінка і \\
ймовірність настання \\
ризиків, помилки \\
виявлені в обліку \\
експортно-імпортних \\
операцій та причини \\
їх виникнення \\
\end{tabular} & $\begin{array}{l}\text { Щомісячно, головний } \\
\text { бухгалтер, керівник } \\
\text { служби внутрішнього } \\
\text { контролю }\end{array}$ \\
\hline \begin{tabular}{|l|} 
Зведена відомість \\
результатів пере- \\
вірки оподаткування \\
зовнішньоекономічних \\
операцій
\end{tabular} & $\begin{array}{l}\text { Надання інфрормації } \\
\text { про правильність } \\
\text { визначення бази } \\
\text { оподаткування та } \\
\text { сум нарахованих і } \\
\text { сплачених податків із } \\
\text { здійснених операцій }\end{array}$ & \begin{tabular}{|l|} 
Суми нарахованих \\
та сплачених податків \\
за результатами \\
здійснення ЗЕД \\
в розрізі їх видів, \\
встановлені \\
відхилення \\
та причини їх \\
виникнення, шляхи \\
усунення \\
\end{tabular} & $\begin{array}{l}\text { Щомісячно, керівник } \\
\text { юридичного відділу, } \\
\text { головний бухгалтер }\end{array}$ \\
\hline $\begin{array}{l}\text { Відомість результатів } \\
\text { перевірки } \\
\text { трансорертного } \\
\text { ціноутворення на } \\
\text { підприємстві }\end{array}$ & $\begin{array}{l}\text { Надання інформації } \\
\text { щодо правильності } \\
\text { визначення контр- } \\
\text { ольованих операцій, } \\
\text { ризиків здійснення } \\
\text { зовнішньоеконо-- } \\
\text { мічних операцій з } \\
\text { пов'язаними сторо- } \\
\text { нами }\end{array}$ & $\begin{array}{l}\text { Критерії пошуку } \\
\text { контрольованих } \\
\text { операцій; порядок } \\
\text { здійснення вибору } \\
\text { методу визначення } \\
\text { відповідності } \\
\text { ціни принципу } \\
\text { «витягнутої руки»; } \\
\text { оцінка правильності } \\
\text { обчислення рівня цін } \\
\text { у контрольованих } \\
\text { операціях }\end{array}$ & $\begin{array}{l}\text { Раз на рік, } \\
\text { податкові експерти } \\
\text { та консультанти, } \\
\text { керівник юридичного } \\
\text { відділу, головний } \\
\text { бухгалтер }\end{array}$ \\
\hline
\end{tabular}


- визначення правильності відображення доходів від реалізації товарів, робіт та послуг при експортно-імпортних операціях та обчислення бази оподаткування ПдВ та податком на прибуток;

- перевірка правильності розрахунку курсових різниць, їх облікового відображення у складі доходів і витрат підприємства, звітності підприємства;

- перевірка правильності розрахунку податкових різниць при здійсненні зовнішньоекономічних операцій з нерезидентами;

- стан платіжної дисципліни і наявність недоїмок в частині сплати податків від здійснення зовнішньоекономічних операцій;

- встановлення правильності розрахунку та сплати податку на прибуток від доходів, отриманих нерезидентом 3 джерелом їх походження з України;

- встановлення розмірів застосованих санкцій фріскальними органами за порушення в сорері податкового обліку зовнішньоекономічних операцій.

На кожному етапі внутрішнього контролю зовнішньоекономічних операцій результати контролю підлягають відповідному документуванню. Документальне забезпечення результатів внутрішнього контролю ЗЕД в умовах ризику складається 3 двох груп документів: робочі документи суб'єктів внутрішнього контролю за результатами перевірки зовнішньоекономічних операцій в умовах ризику; підсумкові узагальнюючі документи, що складаються за результатами виконаних контрольних процедур.

Завдяки робочим документам суб'єктів внутрішнього контролю відбувається фріксація застосованих прийомів та способів контролю, виконаних контрольних процедур та результатів їх використання. Враховуючи, відсутність належних напрацювань 3 даного питання, за результатами дослідження розроблені фрорми робочих документів суб'єктів внутрішнього контролю, які пропонується використовувати під час перевірки зовнішньоекономічних операцій в умовах ризику (табл. 1).

Прикладне значення запропонованих робочих документів суб'єктів внутрішнього контролю в сорері перевірки зовнішньоекономічних операцій полягає у формуванні оперативних та диференційованих інформаційних потоків про відхилення та порушення в частині здійснення ЗЕД, виникнення ризиків та їх впливу на фрінансові результати діяльності підприємства.

На етапі наступного контролю відбувається оформлення результатів та пропозицій щодо удосконалення системи внутрішнього контролю ЗЕД в умовах ризику. Відповідно повинен складатися Звіт про результати внутрішнього контролю здійснення зовнішньоекономічних операцій та Звіт про результати внутрішнього контролю ризиків ЗЕД. У зазначених підсумкових узагальнюючих документах наводиться перелік виявлених порушень в частині облікового відображення зовнішньоекономічних операцій та ризиків ЗЕД, систематизуються причини їх виникнення, наводиться перелік застосованих прийомів документального і фрактичного контролю та шляхи усунення виявлених порушень 3 метою запобігання їх виникнення в майбутньому.

Висновки. Використання запропонованого методичного забезпечення системи внутрішнього контролю ЗЕД в умовах ризику забезпечить упорядкування і ефрективне здійснення ЗЕД, сприятиме дотриманню політики управлінського персоналу в частині збереження майна підприємства та забезпечить правильне документування та облікове відображення зовнішньоекономічних операцій. Розроблена методика внутрішнього контролю із виділенням джерел інсрормації, контрольних процедур та етапі здійснення внутрішнього контролю ЗЕД, розроблені фрорми робочих документів суб'єктів внутрішнього контролю, дозволять отримувати користувачам достовірну інсрормацію та приймати ефективні управлінські рішення в сорері налагодження євроінтеграційних зав'язків.

\section{СПИСОК ВИКОРИСТАНИХ ДЖЕРЕЛ:}

1. Бовтун О.Л. Організація аудиту зовнішньоекономічної діяльності підприємства. Проблеми економіки України. 2012. Вип. 16. С. 13-17.

2. Венцель В.Т. Бухгалтерський облік і контроль експортно-імпортних операцій: теорія, методика, організація : дис. на здобуття наук. ступ. канд. економ. наук за спец. 08.00.09 - бухгалтерський облік, аналіз та аудит (за видами економічної діяльності). Житомирський державний технологічний університет. Житомир, 2012. 345 с.

3. Глущенко Я.І. Внутрішній контроль зовнішньоекономічного договору: інсоормаційно-організаційні та методичні аспекти. Причорноморські економічні студії. 2017. Вип. 16. С. 64-68.

4. Добровольска В.В. Договірний контроль у сфері зовнішньоекономічної діяльності. Ученые записки Таврического національного университета им. В.И. Вернадского. 2013. Т. 26(65). № 2-1 (4. 1). С. 332-340. 
5. Євдокимов В.В., Венцель В.Т. Внутрішній контроль операцій експорту та імпорту товарів. Вісник Донбаської державної машинобудівної академії. 2011. № 3(24). С. 79-84.

6. Лубенченко О.Е. Формування парадигми аудиту зовнішньоекономічної діяльності суб'єктів господарювання. БІЗНЕСІНФОРМ. 2015. № 10. С. 41-46.

\section{REFERENCES:}

1. Bovtun, O.L. (2012). Orhanizatsiia audytu zovnishnoekonomichnoi diialnosti pidpryiemstva [Organization of audit of foreign economic activity of the enterprise]. Problemy ekonomiky Ukrainy, vol. 16, pp. 13-17.

2. Ventsel, V.T. (2012). Bukhhalterskyi oblik i kontrol eksportno-importnykh operatsii: teoriia, metodyka, orhanizatsiia [Accounting and control of export-import operations: theory, methodology, organization]: Dys. na zdobuttia nauk.stup. kand. ekonom. nauk za spetsialnistiu 08.00.09 - bukhhalterskyi oblik, analiz ta audyt (za vydamy ekonomichnoi diialnosti). Zhytomyrskyi derzhavnyi tekhnolohichnyi universytet. Zhytomyr, $345 \mathrm{p}$.

3. Hlushchenko, Ya.I. (2017). Vnutrishnii kontrol zovnishnoekonomichnoho dohovoru: informatsiino-orhanizatsiini ta metodychni aspekty [Internal control of foreign trade agreement: information-organizational and methodological aspects]. Prychornomorski ekonomichni studii, vol. 16, pp. 64-68.

4. Dobrovolska, V.V. (2013). Dohovirnyi kontrol u sferi zovnishnoekonomichnoi diialnosti [Contractual control in the field of foreign economic activity]. Uchenye zapysky Tavrycheskoho natsionalnoho unyversyteta im. V.Y. Vernadskoho, t. 26(65), no. 2-1, pp. 332-340.

5. Yevdokymov, V.V., Ventsel, V.T. (2011). Vnutrishnii kontrol operatsii eksportu ta importu tovariv [Internal control of export and import of goods]. Visnyk Donbaskoi derzhavnoi mashynobudivnoi akademii, vol. 3(24), pp. 79-84.

6. Lubenchenko, O.E. (2015). Formuvannia paradyhmy audytu zovnishnoekonomichnoi diialnosti subiektiv hospodariuvannia [Formation of the paradigm of audit of foreign economic activity of economic entities]. BIZNESINFORM, vol. 10, pp. 41-46. 